УДК 72.012:504 + 504:74:372.8(004)

DOI https://doi.org/10.24919/2308-4863/45-1-12

\title{
Наталія КОЛЕСНИК,
} orcid.org/0000-0001-9384-9369 кандидат педагогічних наук, дочент, доиент кафедри образотворчого мистеитва та дизайну Житомирського державного університету імені Івана Франка (Житомир, Украӥна) kolesnik@zи.edu.иа

Валентина ТАНСБКА, orcid.org/0000-0002-6496-0145

кандидат педагогічних наук, дочент, директор навчально-наукового інституту педагогіки Житомирського державного університету імені Івана Франка

(Житомир, Україна)avd23v@ukr.net

\section{ЕКОЛОГІЧНИЙ ДИЗАЙН У ПРОЄКТНІЙ ДІЯЛЬНОСТІ ЗДОБУВАЧІВ ВИЩОЇ ОСВІТИ}

У статті проаналізовано актуальність дослідження. Визначено, щзо концептуальні ідеї сучасної стратегї реформування освіти в Україні відображено в основних нормативно-правових документах. Авторами виявлено, щцо реалізація стратегічних завдань до дизайну у проєктній діяльності здобувачів вищої освіти засобами екологічного дизайну вимагає нових підходів до переходу кількісних показників ї̈ рівня в якісні документи. Метою роботи є аналіз і розкриття особливостей екологічного дизайну у проєктній діяльності здобувачів вищої освіти шляхом упровадження різноманітних підходів у контексті Свропейського освітнього простору. Методи дослідження: теоретичні (аналіз, синтез, узагальнення, моделювання, проєктування, класифікація, методи екстраполяції та прогностики); емпіричні (онлайн-інтерв 'ювання, анкетування, тестування, бесіда, методи математичної статистики). Авторами виявлено, що здобувачі вищої освіти у Навчально-науковому інституті педагогіки Житомирського державного університету імені Івана Франка оволодівають низкою загальних, інтегральних, фахових, спеціальних компетентностей, утілюють творчі ідеї, креативно мислять над дизайн-проєктами екологічного спрямування, котрим притаманні оригінальність, авторське бачення нового унікального змісту у проєктній діяльності.

Результати дослідження: нині здобувачі вищої освіти під час фахової підготовки оволодівають професійною універсальністю, широким спектром художніх засобів і проєктних методів у контексті екологічного дизайну. Виявлено, що здобувачі вищої освіти під час проєктної діяльності у контексті екологічного дизайну оволодівають професійною універсальністю, широким спектром художніх засобів і проєктних методів, щзо дозволяє їм створювати об' єкти екологічного дизайну різної складності, які продукують візуально-інформаційне середовищуе, забезпечуючи потрібний зв'язок між людиною і середовищем, між людиною і суспільством.

Ключові слова: дизайн, екологічний дизайн, проєктна діяльність, підготовка здобувачів вищої освіти, дизайн-проєкт.

Nataliia KOLESNYK, orcid.org/0000-0001-9384-9369,

Candidate of Pedagogical Sciences, Associate Professor, Associate Professor at the Department of Fine Arts and Design Zhytomyr Ivan Franko State University (Zhytomyr, Ukraine) kolesnik@zu.edu.ua

Valentyna TANSKA, orcid.org/0000-0002-6496-0145

Candidate of Pedagogical Sciences, Associate Professor, Director of the Educational and Research Institute of Pedagogics Zhytomyr Ivan Franko State University (Zhytomyr, Ukraine)avd23v@ukr.net

\section{ECOLOGICAL DESIGN IN PROJECT ACTIVITY APPLICANTS OF HIGHER EDUCATION}

In the article the author analyzes the relevance of the research. It is determined that the conceptual ideas of the modern strategy of education reform in Ukraine are reflected in the main legal documents. The authors found out that the 
implementation of strategic objectives for the training of higher education applicants by means of ecological design requires new approaches to the transition of quantitative indicators of its level into qualitative documents. The aim of the article is to analyze and reveal the features of ecological design in the project activities of higher education seekers by introducing various approaches to educational activities as a condition for the integration of Ukrainian education in the European educational space. Research methods: theoretical (analysis, synthesis, generalization, modeling, design, classification, methods of extrapolation and forecasting); empirical (online interviews, questionnaires, testing, interviews, methods of mathematical statistics). The authors found that graduates of the Educational and Scientific Institute of Pedagogy of Zhytomyr Ivan Franko State University master a number of general, integral, professional, special competencies, embody creative ideas, think creatively about environmental design projects, where the author's originality is inherent. unique in project activities. The results of the research: today higher education applicants in the process of professional training by means of ecological design have professional versatility as well as a wide range of artistic means and design methods. The study found that graduates in the process of project activities in the context of environmental design have professional versatility, a wide range of artistic tools and design methods, which allows them to create environmental design objects of varying complexity, creating a visual information environment, providing the necessary the connection between man and the environment, between man and society.

Key words: design, ecological design, project activities, training of applicants for higher education, design project.

Постановка проблеми. Модернізація всіх ланок освіти і реалізація Нової української школи ставить нові вимоги до підготовки здобувачів вищої освіти та їхньої професійної компетентності. Формування професійної компетентності здобувачів вищої освіти стає одним із пріоритетних завдань закладів вищої освіти, оскільки саме на фахівців нового покоління покладена місія із креативного вирішення будь-яких поставлених завдань або життєвих ситуацій, розвитку власної країни, дбайливого ставлення до ії історичної і культурної спадщини. Майбутнє української нації - це творчий і відповідальний фахівець, який постійно працює над собою; здатний створювати авторські навчальні програми; обирати підручники, методи, стратегії, способи і засоби навчання; активно виражати фахову думку і застосовувати проєктні технології у межах авторської ідеї. Ці твердження щодо забезпечення високого рівня професійної підготовки здобувачів вищої освіти відображено у нормативно-правових актах (вітчизняних і закордонних), таких як Закон України «Про вищу освіту», Концепція Нової української школи, Професійний стандарт для викладачів візуального мистецтва Америки (Professional Standards for Visual Arts Educators), Положення щодо проходження сертифікації учителів мистецтва Америки (Art Teacher Certification), професійного розвитку вчителів Європи (Education and Training 2020 Thematic Working Group «Professional Development of Teachers»).

Актуальність дослідження підсилюється низкою виявлених суперечностей: між потребою суспільства в екологічному дизайні, вимогами освітнього простору сьогодення щодо професійної компетентності здобувачів вищої освіти, здатних працювати за інноваційними методиками, використовуючи новітні форми, методи і технології навчання, коли головний акцент робиться на дизайн-проєктуванні та відсутністю систематизованого наукового знання і методики фахової підготовки; між традиційною системою професійної підготовки здобувачів вищої освіти та необхідністю використання проєктних технологій, яка передбачає реалізацію інтегративних зв' язків між навчальними дисциплінами (використання всіх здобутих знань, умінь, навичок і творчих здібностей), спрямованих на формування професійної компетентності, готовності організовувати проєктну діяльність, підпорядковану меті і завданням авторської ідеї дизайн-проєкту; між необхідністю формувати професійну компетентність здобувачами вищої освіти із грунтовними знаннями використання творчого проєктування об'єктів екологічного дизайну, організовувати проєктну діяльність, створювати проєкти та недостатнім організаційно-методичним забезпеченням цього процесу у закладах вищої освіти.

Відтак очевидним є пошук нових наукових підходів до практичного вирішення зазначеної проблеми, створення педагогічних умов для формування професійної компетентності здобувачів вищої освіти засобами проєктної діяльності з екологічного дизайну.

Аналіз досліджень. Проаналізувавши низку джерел історико-мистецтвознавчої літератури, ми зауважимо, що у часи еллінської культури велися дискусії про співвідношення краси та утилітарності, які зводилися до ідеї єдності краси, мудрості і блага як проявів найкращих людських цінностей (Сократ, Платон). Зовнішні функціональні складники і внутрішні якості (інтелект, критерієм найкращого піднесення якого $\epsilon$ мудрість; емоційна сфера, критерієм оптимального піднесення якої є краса) асоціювались із людиною у типовому розумінні, з інтегрованою особистістю, яка, у свою чергу, знаходиться в органічній єдності із довкіллям. 
Основне завдання екологічного дизайну у проєктній діяльності здобувачів вищої освіти - вдосконалювати і розширювати почуття прекрасного, навчити бачити красу рідної природи, красу творчої праці, навколишньої дійсності. Екологічний дизайн орієнтований на екологічну культуру.

Історичний аналіз розвитку дизайну в Україні в історико-теоретичному і дієво-практичному аспектах

В аспекті нашої проблеми ми акцентуємо увагу на важливих тенденціях, які стали основою екологічного дизайну у проєктній діяльності здобувачів вищої освіти, що простежується через екологічний синтез соціального і природного середовища (Кузеляк, 2001 : 123).

Після Промислової Революції більшість пропозицій у цій сфері формувалися на принципах екологічно нестійкого дизайну. Архітектор-дизайнер Віктор Папанек припустив, що промисловий дизайн було знищено завдяки створенню нових типів постійного сміття, вибору матеріалів і процесів, які забруднюють повітря (Papanek, 1972 : 52). Через вищезазначені проблеми Річард Бакмінстер Фуллер підтвердив, що дизайн відіграє важливу роль у визначенні основних світових проблем (Margolin, 1997 : 85).

У 1971 р. ландшафтний архітектор Ян МакХарг у своїй книзі «Дизайн із природою» популяризував систему аналізу місцевості задля того, щоб скласти повне уявлення про якісні ознаки місця. Мак-Харг надав кожному якісному аспекту місцевості свій шар: історія, гідрологія, топографія, рослинність і т.д. Така система стала основою сучасної Геоінформаційної системи (ГІС) - універсального інструмента, який використовується, зокрема, в охороні природи і практиці проєктування екологічного ландшафту (пізніше, у 2015 році, ідею багаторівневого аналізу місцевості для створення якісного натуралістичного ландшафтного дизайну запропонували Томас Райнер і Клаудія Вест).

1978 р. Пермакультура. Білл Моллісон та Девід Холмгрен увели у використання цей термін для системи проєктування регенеративних антропогенних екосистем.

1994 р. Девід Орр у своїй книзі «3 думками про Землю: про освіту, довкілля і перспективу людства» склав серію есе на тему «інтелектуальності екологічного дизайну» і створення здорових, витривалих, простих, правильних, процвітаючих громад.

1994 р. Канадські біологи Джон Тодд і Ненсі Тодд у своїй книзі «Від екоміста до живих механізмів» описують настанови і норми екологічного дизайну.

2000 р. Інститут Екоза пропонує Сертифікацію екологічного дизайну, навчаючи дизайнерів робити дизайн разом із природою.
2004 р. Фритьоф Капра у своїй книзі-підручнику із науки про живі системи «Приховані зв'язки: наука для сталого життя» розглядає застосування нового мислення науковцями-природознавцями (біологами) до нашого розуміння соціальної організації.

2004 р. Кенні Осабель, який увів до вжитку слово «біонер», представив книгу «Інструкції із експлуатації природи», де скомпілював особисті історії найвидатніших за новаціями екологічних дизайнерів світу.

У 1992 році на конференції «Порядок денний 21: Стратегія саміту Землі для спасіння нашої планети» висунуто пропозицію, що у нашому світі відбувається таке виробництво і споживання енергії, яке не може бути стійким. У світлі цього дизайнерська професія стає не такою, що розробляє нові продукти, але такою, яка оновлює та переосмислює саму дизайнерську культуру. Теоретик у галузі дизайну Клів Ділнот зазначив, що дизайн стає засобом впорядкування світу, а не просто засобом надання форми товарам (Clive Dilnot, 1982 : 144). На конференції було підкреслено, що дизайнерам варто кинути виклик проблемам, які встали перед людством. Ці проблеми були означені за шістьма темами: якість життя, ефективне використання природних ресурсів, захист загального надбання людства, управління людськими поселеннями, використання хімічних речовин та управління промисловими відходами, а також сприяння глобальному економічному зростанню (Margolin, 1997 : 91).

Отже, здійснений контент-аналіз дослідження історичних аспектів розвитку і становлення екологічного дизайну у проєктній діяльності здобувачів вищої освіти засвідчив відсутність комплексного підходу до цієї проблеми і системного бачення шляхів іiі наукового розв'язання. Оскільки історичні етапи становлення екологічного дизайну у проєктній діяльності здобувачів вищої освіти лише частково висвітлені у мистецтвознавстві, вони також потребують суттєвого доопрацювання. Розуміння цілісної картини проблематики зазначеного дослідження неможливе без розгляду впливу соціально-комунікативного аспекту на різні сфери взаємодії між людиною і навколишнім середовищем.

Мета статті. Мета роботи, яка $є$ частиною нашого дослідження, - розкриття особливостей екологічного дизайну у проєктній діяльності здобувачів вищої освіти шляхом упровадження різноманітних підходів у контексті Свропейського освітнього простору.

Виклад основного матеріалу.

Зазначимо, що здобувачі вищої освіти у Навчально-науковому інституті педагогіки 
Житомирського державного університету імені Івана Франка оволодівають низкою загальних, інтегральних, фахових і спеціальних компетентностей, утілюють творчі ідеї, креативно мислять над дизайн-проєктами екологічного спрямування; їм притаманні оригінальність, авторське бачення нового унікального змісту у проєктній діяльності.

У контексті нашого дослідження здійснено контент-аналіз базових понять.

Екологічний дизайн - це інтеграційна та екологічно відповідальна дисципліна у сфері дизайну. Вона допомагає поєднати розпорошені зусилля зеленої архітектури, екологічно стійкого сільського господарства, екології відновлення та інших напрямків.

Префікс «еко» використовується приблизно у дев'яти десятках наукових дисциплін, зокрема «Екомісто», «Екоменеджмент», «Екотехнологія» та «Екоархитектура». Вперше цей префікс використав Джон Баттон у 1998 році. На самому початку розвитку природа екологічного дизайну означала «додавання до»: екологічного чинника до дизайнерського процесу. Але пізніше він сфокусувався на деталях практики екодизайну: продукційній системі або промисловості загалом (Willis, 1991).

На думку М. М. Близнюка, екологічний дизайн (частіше вживають слово «екодизайн») - це створення екологічно безпечного середовища існування людини (Близнюк, 2017 : 141). Принципи екологічного дизайну сформовані на основі принципів, які відносяться до різноманітних дисциплін, таких як екологія, енергозберігання, ландшафтна архітектура та естетика.

Залучаючи до моделей життєвого циклу потоки енергії і матеріалів, екологічний дизайн увійшов до складу нового міждисциплінарного предмету промислової екології. Промислова екологія визначає наявність концептуальних моделей, отриманих від природних екосистем, а також структури для осмислення і створення понять із питань довкілля і технологій.

Особливістю екодизайну є врахування характеру, віку, соціального статусу і навіть темпераменту мешканців. Основним завданням екодизайнера $€$ залучення до життєвого простору людини якомога більше позитивної енергії, що вдається йому за допомогою рослин. Більшість людей недооцінюють значення кімнатних квітів, вважаючи, що квіти є лише прикрасою будинку і ліками. Вони навіть не передбачають, що квіти здатні відкрити перед людиною цілий світ гармонії, очистити будинок і захистити іiі від неприємностей. Квіти допомагають розвивати творчі здібності, чудово впливають на серцево-судинну систему, на фізичний, психологічний та енергетичний стани організму людини (Дубовий, 2019 : 7).

Живі організми існують у різних системах збалансованих симбіотичних стосунків. Екологічний рух кінця $\mathrm{XX}$ століття грунтувався на розумінні того, що порушення цих відносин призводить до серйозного руйнування природних екосистем. Незважаючи на те, що винахід засобів використання чистої енергії урегулював екологічний баланс, зростання населення після промислової революції призвело до аномальних екологічних змін (John McHale, 1969 : 66).

Екологічний дизайн розуміють як термін, визначений Сім Ван дер Ріном та Стюартом Коуеном, як «будь-яку форму дизайну, що зводить до мінімуму екологічно руйнівний вплив за рахунок інтеграції себе із процесами живої природи» (Van der Ryn S., Cowan S., 1996 : 18).

Під час дослідження нами вивчено деякі аспекти використання екологічного дизайну у проєктній діяльності здобувачів вищої освіти, уточнено та обгрунтовано критерії, показники і рівні сформованості професійної компетентності здобувачів вищої освіти під час проєктної діяльності.

Зауважимо, що контрольний етап експерименту продемонстрував наявність рівня сформованості професійної компетентності здобувачів вищої освіти під час творчої проєктної діяльності засобами екологічного дизайну (переважно низький і достатній рівні), причому однорідність вибірки у контрольній та експериментальній групах перевірено за допомогою критерію Пірсона $\chi_{2}$, що доводить відсутність статистично значущих відмінностей між ними.

Формувальний етап мав на меті перевірку та обгрунтування ефективності умов формування професійної компетентності здобувачів вищої освіти під час творчої проєктної діяльності засобами екологічного дизайну. Авторами доведено, що отримані результати формувального етапу зафіксовано під час контрольного етапу експерименту; вони є однозначними і вичерпно демонструють позитивну динаміку у рівнях сформованості професійної компетентності здобувачів вищої освіти під час творчої проєктної діяльності засобами екологічного дизайну за визначених умов. Нами зафіксовано визначальні зміни в експериментальній групі - частка здобувачів із високим і достатнім рівнями зросла суттєво, а у контрольній групі змін майже не відбулось. Отже, експериментальна частина дослідження продемонструвала, що організація освітнього процесу на основі визначених умов сприяє підвищенню 
ефективності формування професійної компетентності здобувачів вищої освіти під час творчої проєктної діяльності засобами екологічного дизайну. Отримані результати ми перевірили за допомогою критерію Пірсона $\chi_{2}$, що є обгрунтуванням зазначеного висновку.

На вербальному етапі освітнього процесу активуються і поглиблюються регіональні особливості, а саме: автентичне мислення, українські національні та зарубіжні культурні надбання і здобутки, зокрема Житомирщини, що сприймались як об'єкти і зразки екологічного дизайну. Під час творчої проєктної діяльності здобувачі вищої освіти вдосконалюють власне естетичні ідеали відповідно до природної спрямованості способу природокористування за напрямами, визначеними А. Є. Климовим: людина-людина, людина-природа, людина-техніка, людина-знакові системи, людина-художні образи (Найдьонов, 2010 : 198).

Висновки. Отже, здобувачі вищої освіти під час проєктної діяльності у контексті екологічного дизайну оволодівають професійною універсальністю, широким спектром художніх засобів і проєктних методів, що дозволяє їм створювати об'єкти екологічного дизайну різної складності, які формують візуально-інформаційне середовище, забезпечуючи потрібний зв'язок між людиною і середовищем, між людиною і суспільством.

\section{СПИСОК ВИКОРИСТАНИХ ДЖЕРЕЛ}

1. Близнюк М. М. Екологічний дизайн: теоретичні основи, принципи, освітня складова. Вісник Львівської наиіональної академії мистещтв. 2017. Вип. 33. С. 141-153.

2. Дубовий О. В., Блажкевич Т. П., Дубовий В. І. Екологічний дизайн : навч. посіб. Херсон : ОЛДІ-ПЛЮС, 2019. 362 с.

3. Найдьонов М. І. Оцінка громадянами творчих спеціальностей за українським стандартом престижності професій. Актуальні проблеми психології. 2010. Вип. 11. С. 196-204.

4. Кузеляк Р.Р. Дизайн середовища. Реклама і дизайн на порозі XXI сторіччя : зб. матеріалів доп. учасн. Міжнар. наук.-практ. конф. Київ, 2001. С. 122-124.

5. Clive Dilnot. Design as a Society Significant Activity: An Introduction, Design studies. 1982. 144 p.

6. Kolesnyk N. Ye., Kubrak S. V., Yavorska T. Ye., Vitvytska S. S. Information and Media Literacy and «Cloud» Technologies in Training of Higher Education Applicants: the Sustainable Development Paradigm. Universal Journal of Educational Research. 2020. Vol. 8. № 6. P. 2668-2677. URL: http://www.hrpub.org/download/20200530/UJER51-19515696. pdf (дата звернення: 09.12.2021).

7. John McHale. An Ecological Overview. In The Future of the Future. New York : George Braziller, 1969. P. 66-74.

8. Van der Ryn S, Cowan S. Ecological Design. Island Press. 1996. 18 p.

9. Victor Margolin. Design for a Sustainable World. Design Issues. 1988. Vol. 14 (2). 91 p.

10. Victor Papanek, Design for the Real World: Human Ecological and Social Change. Toronto/New York/London: Bantam books. 1972. 387 p. URL: https://monoskop.org/images/f/f8/Papanek_Victor_Design_for_the_Real_World.pdf (дата звернення: 15.12.2021).

\section{REFERENCES}

1. Blyzniuk M. M. Ekolohichnyi dyzain: teoretychni osnovy, pryntsypy, osvitnia skladova. [Ecological design: theoretical foundations, principles, educational component]. Bulletin of the Lviv National Academy of Arts, 2017, Output. 33. pp. 141-153 [in Ukrainian].

2. Dubovyi O. V., Blazhkevych T. P. , Dubovyi V. I. Ekolohichnyi dyzain : navch. posib. [Ecological design: a textbook]. Kherson : OLDI-PLIuS, 2019. 362 p. [in Ukrainian].

3. Naidonov M. I. Otsinka hromadianamy tvorchykh spetsialnostei za ukrainskym standartom prestyzhnosti profesii [Citizens' assessment of creative specialties for Ukrainian standard of prestige of professions ]. Actual problems of psychology, 2010. Output. 11. pp. 196-204 [in Ukrainian].

4. Kuzelyak R. R. Dyzayn seredovyshcha [Environment design]. Advertising and design on the threshold of the XXI century: coll. materials add. participant International. scientific-practical conf. Kyiv, 2001. pp. 122-124 [in Ukrainian].

5. Clive Dilnot. Design as a Society Significant Activity: An Introduction, Design studies. 1982. 144 p.

6. Kolesnyk N. Ye., Kubrak S. V., Yavorska T. Ye., Vitvytska S. S. Information and Media Literacy and «Cloud» Technologies in Training of Higher Education Applicants: the Sustainable Development Paradigm. Universal Journal of Educational Research. 2020. Vol. 8. № 6. P. 2668-2677. URL: http://www.hrpub.org/download/20200530/UJER51-19515696. pdf (accessed 09.12.2021).

7. John McHale. An Ecological Overview. In The Future of the Future. New York : George Braziller, 1969. P. 66-74.

8. Van der Ryn S, Cowan S. Ecological Design. Island Press. 1996. 18 p.

9. Victor Margolin. Design for a Sustainable World. Design Issues. 1988. Vol. 14 (2). 91 p.

10. Victor Papanek, Design for the Real World: Human Ecological and Social Change. Toronto/New York/London: Bantam books. 1972. 387 p. URL: https://monoskop.org/images/f/f8/Papanek_Victor_Design_for_the_Real_World.pdf ((accessed 15.12.2021) 